\title{
Allelopathic properties of Calliandra haematocephala Hassk. extracts and fractions as an alternative for weed management in quinoa and rice crops
}

\author{
Victor Rueda-Ayala ${ }^{1}$ - Luis Ramos-Guerrero ${ }^{2}$ Paul Vargas-Jentzsch ${ }^{3} \cdot$ Betty Hernández $^{4}$. Mats Höglind ${ }^{1}$. \\ Ingrid Toscano ${ }^{5} \cdot$ Dayana Borja $^{5} \cdot$ Lorena Goetschel $^{5} \cdot$ Dionisio Andújar ${ }^{6}$
}

Received: 20 September 2019 / Revised: 10 November 2019 / Accepted: 17 March 2020 / Published online: 30 March 2020

(c) The Author(s) 2020

\begin{abstract}
In this study, aqueous extracts of Calliandra haematocephala Hassk. leaves and inflorescences were tested on seeds of quinoa (Chenopodium album L.) and rice (Oryza sativa L.), and on some of the most noxious-associated weeds, Chenopodium album L. and Holcus lanatus L. in quinoa, and Echinochloa crus-galli (L.) P. Beauv., Echinochloa colona L., Eclipta prostrata L. and Rottboellia cochinchinensis (Lou.) W.D. Clayton in rice. The objectives were to identify extract concentrations at which 50 and $90 \%$ of germination $\left(\mathrm{GR}_{[50,90)}\right)$ and radicle elongation $\left(\mathrm{RR}_{[50,90]}\right)$ were inhibited, to fractionate inflorescence extracts for facilitating identifying the chemical group causing allelopathic effects, and to evaluate the fraction showing the stronger weed suppression effects and the least crop damage. Increasing extract concentration rates $(0,6.25,12.5,25,50$ and $100 \%$ crude extract) were applied to seeds of target crops and weeds. Flower extracts at rates $<0.30$ produced $\mathrm{GR}_{[50]}$ and $\mathrm{RR}_{[50]}$ on H. lanatus, and $\mathrm{GR}_{[90]}$ and $\mathrm{RR}_{[90]}$ in C. album, while quinoa seeds were not affected. Rice and its target weeds were minimally affected by flower extracts, whereas radicle elongation of all species was significantly reduced. A concentration rate $>0.52$ caused the $\mathrm{RR}_{[50]}$ on rice and all its target weeds. Fractions were quantitatively and qualitatively analysed to detect phytochemical groups, using specific chemical reagents and thin-layer chromatography (TLC). The fraction F3 from aqueous flower extract showed a high content of flavonoids, assumed as the potential allelochemical substance. Total flavonoid content in $\mathrm{F} 3$ was quantified as $2.7 \mathrm{mg}$ of quercetin per $\mathrm{g} \mathrm{F} 3$, i.e., $12.8 \mathrm{mg}$ of quercetin per $\mathrm{g}$ of inflorescence material. Additionally, field equivalent extract rates obtained from the harvested fresh inflorescence biomass could be determined. These rates ranged between 90 and $143 \mathrm{~mL} \mathrm{l}^{-1}$ of $\mathrm{F} 3$ aqueous fraction, while for ethanol $\mathrm{F} 3$ were $131 \mathrm{~mL} \mathrm{l}^{-1}$. Our results are encouraging for finding sustainable and ecologically friendly alternatives for weed management in crops of high nutritional value, contributing also to counteract the growing problem of herbicide resistance.
\end{abstract}

Keywords Dose-response · Bioassay · Germination reduction · Radicle elongation reduction · Flavonoids · Quercetin · Field equivalent rate

Communicated by P. Wojtaszek.

Electronic supplementary material The online version of this article (https://doi.org/10.1007/s11738-020-03041-z) contains supplementary material, which is available to authorized users.

Victor Rueda-Ayala patovicnsf@gmail.com

Extended author information available on the last page of the article

\section{Introduction}

The advent of synthetic pesticides in the 1930s and 1940s shaped agriculture as it is known today (Hall et al. 2000; Rattner 2009). Crop yields have increased remarkably with the use of synthetic fertilizers and pesticides. Almost one of every ten people in the world become ill due to the consumption of contaminated food or water, due to microbial factors and chemical contamination, the latter involving pesticide residues (World Health Organization 2017). Aspects referred to water and soil pollution and their persistence in the environment due to the misuse of pesticides are also well documented (Schwarzenbach et al. 2010; Morrissey et al. 
2015; Yadav et al. 2015). Vonberg et al. (2014), based on monitoring data of a shallow aquifer exposed to the effects of intensive agriculture in western Germany, reported the presence of atrazine (in concentrations above $0.1 \mu \mathrm{g} \mathrm{l}^{-1}$ ) after 20 years of being banned. Therefore, the need of alternative crop management strategies, such as the use of natural products, is evident. Natural pesticides may show advantages, assuming that their persistence in the environment is considerably shorter than those synthetically produced.

Weeds cause huge yield losses around the globe. Weed control strategies vary largely among cropping systems, environmental conditions and farm economic factors (Rueda-Ayala et al. 2010), but mainly includes the application of synthetic herbicides (Thill et al. 1991). Continuous use of the few available active ingredients of herbicides has enhanced the selection of resistant weed populations. These populations have increased immensely in the last decades, thus demanding that weed management strategies evolve accordingly (Weis et al. 2012; Colbach et al. 2016).

Alternative substances for weed control can also be of natural origin. The primary source for many organic herbicides is chemicals released by plants, which have direct or indirect detrimental effects on germination, growth or development of other plants (Webber et al. 2012; Koocheki et al. 2013). Different natural products have already been tested and marketed. However, their efficacy is generally low, compared with synthetic products (Cordeau et al. 2016). The phytotoxic effect of aqueous extracts of different plant materials used as bioherbicides have been widely explored, from in-vitro bioassays to greenhouse and field experiments (de Albuquerque et al. 2011; Bhadoria 2011; Rueda-Ayala et al. 2015). Allelopathic effects may be attributed to phenolic compounds found in one or various plant parts, and these effects can be strengthen by mixing compounds of different plant species (Reigosa and Pazos-Malvido 2007). Puig et al. (2018) identified allelopathic activity and the chemical composition of different species of the genus Eucalyptus (Myrtaceae). Phytotoxic effects of E. globulus aqueous extracts affected the germination and radicle elongation of some crops and weeds with specific modes of action on different target species. Similarly, (Souto et al. 1994) identified allelopathic effects on four forestry species. The soils associated with those studied species appeared to be responsible for the toxic effects, indicating release of allelopathic compounds by the plant roots.

Many growth inhibitors found in plants have been effective for pathogen and weed control (Xuan et al. 2005). The high number of allelophatic compounds existing in various plant species need to be assessed, to determine their potential as alternatives to synthetic herbicides, i.e., as bioherbicides. From leaves of Calliandra species, some compounds with insecticidal properties have been identified, e.g., nonproteic imino acids (Romeo 1984). Raja et al. (2017) synthesized nanoparticles from leaf extracts of Calliandra haematocephala Hassk. with antibacterial activity. To the best of our knowledge, nothing is known about allelopathic properties of this plant against weeds in cropping systems. Prior to this study, a high suppressive effect was observed on germination of numerous weed species when soils were covered by vegetative and inflorescence structures (mulch) of C. haematocephala shrubs. Furthermore, if some seeds did germinate, they became withered a couple of days later, even when water availability was sufficient. These facts motivated our interest on testing plant extracts of this shrub species.

Testing, validating and adapting the use of bioherbicides to the local conditions and important crops of every agricultural region should be carried out. In this study, aqueous and ethanol-based extracts from leaves and inflorescence of C. haematocephala were prepared with the aim of determining the presence of allelopathic compounds. The specific objectives were, (i) to identify the extract concentrations at which 50 and $90 \%$ of germination and radicle elongation were inhibited in seeds of quinoa (Chenopodium quinoa Willd.) and rice (Oryza sativa L.), including their associated most problematic weeds in the Ecuadorian context, (ii) to fractionate inflorescence extracts for facilitating identifying the chemical group causing those effects, and (iii) to evaluate the fraction showing the stronger weed suppression effects and the least crop damage.

\section{Materials and methods}

The study was carried out in the laboratories of the Ecuadorian Agency for Quality Assurance in Agriculture, AGROCALIDAD $\left(0^{\circ} 12^{\prime} 52^{\prime \prime} \mathrm{S} ; 78^{\circ} 24^{\prime} 40^{\prime \prime} \mathrm{W}\right)$, near Quito, Ecuador. Experiments were implemented in two phases: (1) detection of allelopathic effects in C. haematocephala extracts, and (2) fractionation of those extracts for chemical screening and identification of the possible involved substances. Leaves $(645 \mathrm{~g})$ and inflorescences $(1110 \mathrm{~g})$ were collected from $C$. haematocephala shrubs (10 plants) on neighboring gardens, during 2015, 2016 and 2017 (Table 1). Prior to extraction, all plant material was washed with a $1 \%$ solution of Sodium hypochlorite, rinsed with deionized water, dried in a stove at $40{ }^{\circ} \mathrm{C}$ for $24 \mathrm{~h}$, then stored at $-20^{\circ}$ until use.

\section{Detection of allelopathic properties}

Aqueous extracts were obtained separately from leaves and from inflorescence of $C$. haematocephala. Different amounts of solvent per plant part, according to the requirements of each experiment, were used to obtain the extracts. Leaves of C. haematocephala are drier than inflorescences, thus they required more solvent to produce a uniform extract structure. 
Table 1 Details for the preparation of C. haematocephala crude aqueous extracts: plant material used, fresh weight, volume of solvent applied per $50 \mathrm{~g}$ fresh weight, amount of extract obtained, con- centration and experimental use on target plant species, $C$. album (CHEAL), H. lanatus (HOLLA), E. colona (ECHCO), E. crus-galli (ECHCG), E. prostrata (ECLAL) and R. cochinchinensis (ROOEX)

\begin{tabular}{|c|c|c|c|c|c|c|c|c|}
\hline \multicolumn{2}{|c|}{ Experiment } & \multicolumn{3}{|c|}{ Plant material* } & \multicolumn{2}{|c|}{ Extract retrieved } & \multicolumn{2}{|c|}{ Target species } \\
\hline $\mathrm{Nr}$. & Type & Structure & Weight (g) & Solvent (mL) & Amount (mL) & $\begin{array}{l}\text { Concentration } \\
\left(\mathrm{g} \mathrm{mL}^{-1}\right)\end{array}$ & Crop & Weeds \\
\hline 1 & $\begin{array}{l}\text { Dose-response } \\
\text { Bioassay }\end{array}$ & Leaf & 328 & 20 & 107 & 2.5 & Quinoa & $\begin{array}{l}\text { CHEAL } \\
\text { HOLLA }\end{array}$ \\
\hline 2 & $\begin{array}{l}\text { Dose-response } \\
\text { Bioassay }\end{array}$ & & 313 & 20 & 102 & 2.50 & Quinoa & $\begin{array}{l}\text { CHEAL } \\
\text { HOLLA }\end{array}$ \\
\hline 3 & $\begin{array}{l}\text { Dose-response } \\
\text { Bioassay }\end{array}$ & Flower & 285 & 15 & 141 & 3.33 & Quinoa & $\begin{array}{l}\text { CHEAL } \\
\text { HOLLA }\end{array}$ \\
\hline 4 & $\begin{array}{l}\text { Dose-response } \\
\text { Bioassay }\end{array}$ & & 276 & 15 & 136 & 3.33 & Quinoa & $\begin{array}{l}\text { CHEAL } \\
\text { HOLLA }\end{array}$ \\
\hline 5 & $\begin{array}{l}\text { Dose-response } \\
\text { Bioassay }\end{array}$ & & 434 & 15 & 238 & 3.33 & Rice & $\begin{array}{l}\text { ECHCG } \\
\text { ECHCO } \\
\text { ECLAL } \\
\text { ROOEX }\end{array}$ \\
\hline 6 & $\begin{array}{l}\text { Fractionation }^{\dagger} \\
\text { and Bioassay }\end{array}$ & Flower & 53 & 18 & 67 & 2.78 & Quinoa & $\begin{array}{l}\text { CHEAL } \\
\text { HOLLA }\end{array}$ \\
\hline 7 & $\begin{array}{l}\text { Fractionation }^{\dagger} \\
\text { and Bioassay }\end{array}$ & & 53 & $90^{\ddagger}$ & 85 & 0.56 & Quinoa & $\begin{array}{l}\text { CHEAL } \\
\text { HOLLA }\end{array}$ \\
\hline
\end{tabular}

*Collected in 2015 (exps. 1 and 3), in 2016 (exps. 2, 4, 6 and 7) and 2017 (exp. 5)

${ }^{\dagger}$ Aqueous and ethanol-based crude extracts were partitioned into five fractions (F1-F5), and tested together with the crude extract (F0) and the corresponding blank, deionized water or $10 \%$-ethanol solution

¥A 70\%-ethanol solution was used instead of deionized water (see "Fractionation of flower extracts")

In the case of extractions for fractioning, it was required to have a more diluted crude extract, to facilitate the phytochemical screening during the qualitatively analyses. A similar method as Rueda-Ayala et al. (2015) was used, but applying less deionized water to generate a highly concentrated stock solution (crude extract). Details for retrieving both, inflorescence (hereafter 'flower extract') and leaf extract and for carrying out bioassays is shown in Table 1 and Figure A1. Plant material, in $50 \mathrm{~g}$ at a time, were macerated and ground with liquid nitrogen, then dispersed in deionized water and Ultra-Turrax mixed for $1 \mathrm{~min}$. This mixture was filtered on a vacuum pump through a Büchner funnel with qualitaitve filter paper. The remaining material was further pressed to retrieve the liquid and then filtered. The collected mixture was centrifuged at $3500 \mathrm{rpm}$ for $15 \mathrm{~min}$ and the supernatant removed to purify the extract. Depending on the amount of deionized water added, extract concentrations varied (Table 1).

Allelopathic properties were studied via dose-dependent bioassays. Two economically important crops in the Ecuadorian context, including their most noxious weed species, were used as targets: quinoa (Chenopodium quinoa Willd., cultivar Tulcanaza), Chenopodium album L. (CHEAL) and Holcus lanatus L. (HOLLA), representing the Andean region, and rice (O. sativa L.), Echinochloa colona L. (ECHCO), Echinochloa crus-galli (L.) P. Beauv. (ECHCG), Eclipta prostrata L. (ECLAL) and Rottboellia cochinchinensis (Lou.) W.D. Clayton (ROOEX), representing the coastal region. EPPO-code is given according to the EPPO Global Database (https://gd.eppo.int). Concentration rates, 1 (' $100 \%$-extract'), $0.5,0.25,0.125$ and 0.0625 plus a control (0), were derived by adding a dilution series with deionized water to the $100 \%$ crude extracts. Biochemical effects of each concentration on seed germination and seedling radicle elongation of the aforementioned target crops and weeds were tested. Certified crop seeds were acquired from the National Institute of Agronomic Research (INIAP) Santa Catalina, Quito, while weed seeds were collected from cultivated fields, without weed control. Two dose-response bioassays were implemented in quinoa during 2015, using the six extract concentrations, and two during 2017 in rice, using various concentrations of flower extract. In addition, the flower extract was fractionated (see "Fractionation of flower extracts") and used on two bioassays during 2016 in quinoa and target species.

For the bioassays, 20 seeds per target species were placed into petri dishes with filter paper; 1 dish per tested species. All petri dishes were sterilized with ethanol $70 \%$ and UV 
radiation for $30 \mathrm{~min}$. Portions of $3 \mathrm{~mL}$ extract were applied onto the seeds and each petri dish was covered, sealed with Parafilm ${ }^{\circledR}$ and kept inside a growth chamber at $12 \mathrm{~h} / 12 \mathrm{~h}$ day/night length and $24{ }^{\circ} \mathrm{C} / 18{ }^{\circ} \mathrm{C}$. Treatments were applied according to a factorial arrangement of the leaf and flower extracts, the six concentrations and the target species (quinoa and corresponding weeds, on experiments $1-4$; rice and corresponding weeds on experiment 5) in a completely randomized design with three replications. Germination of weed seeds was initially tested on a sample of 100 seeds per species. These seeds were then introduced in a recipient with water, to eliminate non-viable seeds, which were assumed to be the ones floating. The initial germination percentage ranged between 30 and $60 \%$. The same procedure was used to select the seeds for the bioassays, and only 10 germinated seeds were randomly selected for assessment of radicle length. Seed germination and radicle elongation of target species were assessed 4 weeks later, when all seedlings germinated in the control experimental units (concentration 0 ). Seedling germination of $H$. lanatus was delayed one more week in all extract concentrations $>0 \%$.

\section{Fractionation of flower extracts}

For the second experimental phase, two types of crude extracts were prepared: aqueous and ethanol-based (Table 1). Extracts based on $70 \%$ ethanol and aqueous extracts were derived from inflorescence only. Cleaned and dried inflorescence were cut in small pieces, and $50 \mathrm{~g}$ were placed in a beaker glass with $150 \mathrm{~mL} \mathrm{70 \% -ethanol} \mathrm{solution,} \mathrm{covered}$ with aluminium foil and stored in darkness for $48 \mathrm{~h}$. The mixture was filtered on a vacuum pump through a Büchner funnel with qualitative filter paper, then centrifuged at 3500 rpm for $15 \mathrm{~min}$ and the supernatant was removed to purify the extract. The extract solution was concentrated to $85 \mathrm{~mL}$ volume using a rotary evaporator and stored for fractionation and bioassays. Aqueous extracts were prepared as previously described (see "Detection of allelopathic properties" and Table 1). The extracts were fractionated to produce compounds of similar polarities or molecular sizes, as a starting step towards the identification and isolation of the active compounds causing allelopathic effects. At least $27 \mathrm{~mL}$ of each crude extract were used without further dilution in the bioassays as F0 ( $3 \mathrm{~mL}$ per petri dish, 3 target species and 3 repetition samples). Five fractions were generated, using the remaining extract amount, divided in three parts of equal volume, as explained below. The different fractions were obtained via various methods described in Seidel (2005), Otsuka (2005), Evans and Evans (2019) and Ribeiro et al. (2018).

Fractionation with chloroform (F1):A 5\% hydrochloric acid solution was applied drop by drop to $\frac{1}{3}$ of the crude extract until the $\mathrm{pH}$ level dropped to $2-3$. Then, a $20 \%$ sodium hydroxide solution was added drop by drop, to rise the $\mathrm{pH}$ to $10-12$. This solution was washed with $100 \mathrm{~mL}$ chloroform for three times to investigate the presence of alkaloids. The organic phase was concentrated by evaporation to dryness in a rotary evaporator and later reconstituted with sterile water to $50 \mathrm{~mL}$. A $10 \%$ portion of this fraction was preserved for qualitative analysis, together with the resulting aqueous phase.

Fractionation with petroleum ether (F2):Petroleum ether $(100 \mathrm{~mL})$ was added three times through a separation funnel to another $\frac{1}{3}$ of the crude extract, to investigate presence of triterpenes and sterols. The organic phase was evaporated to dryness and reconstituted with sterile deionized water to $50 \mathrm{~mL}$; a $10 \%$ portion and the aqueous phase were preserved for qualitative analysis and further fractionation.

Fractionation with methanol/water (F3 and F4):A 50:50 methanol/water mixture was added to the remaining aqueous phase from F2, for investigation of flavonoids, anthraquinones, tannins, saponins and reducing sugars. This solution was left for maceration for $24 \mathrm{~h}$, then filtered on a vacuum pump and the solid part was solved again in chloroform. The residue was evaporated to dryness and reconstituted with sterile deionized water to $50 \mathrm{~mL}(\mathrm{~F} 3)$, and the $10 \%$ part was preserved for qualitative analysis. The liquid residue from the filtration was also evaporated and reconstituted with sterile water to $50 \mathrm{~mL}(\mathrm{~F} 4)$, preserving the $10 \%$ part for qualitative analysis.

Fractionation with lead acetate and chloroform (F5):The last $\frac{1}{3}$ of crude extract was precipitated by adding a $20 \%$ lead acetate drop by drop, and then vacuum filtered after which the solid residue was disposed off. The liquid phase was extracted with chloroform, dried with anhydrous sodium sulfate and filtered by gravity. These solvents were used to examine the existence of sesquiterpene lactones and coumarines (Tsao and Deng 2004). The resulting chloroform phase was evaporated to dryness, reconstituted with sterile deionized water to $50 \mathrm{~mL}$ and the $10 \%$ part preserved for qualitative analysis.

\section{Bioassays with fractions}

All obtained fractions (F1-F5), crude extracts (F0) and blanks (sterile deionized water and $10 \%$ ethanol) were tested on target species to determine the effects on germination and radicle elongation, via bioassays (Table 1, experiments 6 and 7). The implemented factorial experiment contained two extraction methods, ethanol and aqueous-based (factor method), six fractions (F0-F5) plus one control blank per 
extraction method (factor fractions) and three target plant species (factor target species). The experiment was arranged in a completely randomized design with three repetitions. Management of bioassays and variable assessments were carried out similarly as for the dose-response bioassays (see "Detection of allelopathic properties").

\section{Qualitative and quantitative analysis}

All fractions were analysed by thin-layer chromatography (TLC) for identification of the most important phytochemical groups with allelopathic properties. The mobile phases and developer substances used for TLC identification are described in Table 2. Further qualitative phytochemical group screening was applied, using specific tests and reagents (see "Qualitative and quantitative analysis of fractions"). A standard calibration curve with quercetin was built to quantify flavonoids on the aqueous fraction F3 (Ivanova-Petropulos et al. 2010; Hossain et al. 2013). Quercetin was measured in C. haematocephala flower extract, because flavonoids have been found in the form of quercetin in mimosaceae and fabaceae species (Sulaiman and Balachandran 2012; da Silva et al. 2015). F3 was chosen, because it showed high inhibiting effects on germination and radicle elongation of target species. Standard ethanol solutions $(5 \mathrm{~mL})$ at different concentrations were prepared, 2.0, 1.0, 0.5, $0.25,0.125$ and $0.0625 \mathrm{mg} \mathrm{mL}^{-1}$. A sample of F3 was dissolved in ethanol, at a ratio $1 / 10$ in weight $(0.5 / 5.0 \mathrm{~g}) ; 1.25 \mathrm{~mL}$ ethanol and $0.075 \mathrm{~mL}$ sodium nitrite $(5 \%)$ were added to both, the fraction sample and the standards, and left to rest for $6 \mathrm{~min}$. Then, $0.15 \mathrm{~mL}$ aluminium chloride $(10 \%)$ were added to the mixture, left to rest for $5 \mathrm{~min}$, added $0.5 \mathrm{~mL}$ sodium hydroxide $(1 \mathrm{M})$. The mixture was filled with ethanol to a volume of 2.5 $\mathrm{mL}$. Thirty min later, the fraction sample and standards were evaluated with the spectrophotometer at $510 \mathrm{~nm}$. The fraction density was determined by pycnometry.

The fraction density of major activity was determined by Eq. (1), in which $M 1, M 2$, and $M 3$ represent the weights of empty pycnometer $(11.2 \mathrm{~g})$, pycnometer with deionized water $(12.19 \mathrm{~g})$, and pycnometer with the fraction sample $(12.22 \mathrm{~g})$, respectively, and using a known density of deionized water at $24^{\circ}\left(\rho_{\mathrm{H}_{2} \mathrm{O}}=0.9973 \mathrm{~g} \mathrm{~mL}^{-1}\right)$. The quantity of flavonoids within the fraction of major activity (F3) was calculated with Eq. (2). The constants $a=1.24$ and $b=-0.06$ came from the calibration curve (Figure A2); $A=1.583$ was the determined sample absorbance and $C$ is the concentration of flavonoids. This resulting $C$ value was divided by the used sample weight $(0.498 \mathrm{~g})$ to calculate $\mathrm{mg}$ of quercetin per $\mathrm{g}$ of fraction $\left(C_{f}\right)$. Total concentration of flavonoids was quantified by Eq. (3), as mg quercetin per $\mathrm{g}$ inflorescence material.

$\rho_{f}=\frac{M 3-M 1}{M 2-M 1} \times \rho_{H_{2} O}$

$C=\frac{A+b}{a}$

$C_{f}$ tot $=C_{f} \cdot \rho_{f} \cdot \frac{50 \mathrm{~mL}}{10.65 \mathrm{~g} \text { inflorescence }}$

\section{Statistical analysis}

Treatment effects on germination percentage (log transformed) and radicle length were determined using ANOVA for all bioassays (not shown). Effects of increasing extract concentration dose were described by nonlinear regression,
Table 2 Mobile phases and developer substances used for qualitative analysis by TLC of Phytochemical groups in the crude flower extracts of $C$. haematocephala

\begin{tabular}{|c|c|c|c|c|}
\hline Fraction & Group & Mobile phase & Developer & References \\
\hline $\mathrm{F} 1$ & $\begin{array}{l}\text { Alkaloids } \\
\text { Methanol } \\
(19: 1)\end{array}$ & $\begin{array}{l}\text { Chloroform } \\
\text { Reagent }\end{array}$ & Dragendorff's & Sherma (2000) \\
\hline $\mathrm{F} 2, \mathrm{~F} 4$ & $\begin{array}{l}\text { Sterols and } \\
\text { Terpenes }\end{array}$ & $\begin{array}{l}\text { Petroleum-ethyl } \\
\text { Acetate } \\
(80: 20)\end{array}$ & $\begin{array}{l}\text { Acetic anhydride } \\
+ \text { Sulfuric acid } \\
+ \text { Ethanol }\end{array}$ & Sherma (2000) \\
\hline $\mathrm{F} 3, \mathrm{~F} 4$ & $\begin{array}{l}\text { Flavonoids } \\
\text { Acid-water } \\
(4: 1: 5)\end{array}$ & 1-Butanol-acetic & UV/fluorescence & Ivanova-Petropulos et al. (2010) \\
\hline $\mathrm{F} 3, \mathrm{~F} 4$ & Anthraquinones & $\begin{array}{l}\text { Benzene-ethyl } \\
\text { Acetate-acetic } \\
\text { Acid } \\
(75: 24: 1)\end{array}$ & $\begin{array}{l}\text { Potassium } \\
\text { Hydroxide }\end{array}$ & Sherma (2000) \\
\hline F5 & $\begin{array}{l}\text { Sesquiterpene } \\
\text { Acetone } \\
(60: 40)\end{array}$ & $\begin{array}{l}\text { Dichloromethane- } \\
\text { Hydroxide }\end{array}$ & Potassium & Ivanova-Petropulos et al. (2010) \\
\hline
\end{tabular}


using a log-logistic model with three parameters, Eq. (4), where $f[x(b, d, e)]$ is the expected target-plant response; parameter $b$ denotes the relative slope around $e$, which is the dose reducing $50 \%$ of germination or radicle elongation (GR50 or RR50, respectively); $d$ is the upper asymptote limit and $x$ is the extract concentration (Streibig 1980; Ritz and Streibig 2005). Regression models were tested for lack-of-fit $(\alpha=0.05)$ and via graphical agreement between fitted values and residuals (Belz and Piepho 2012). Model selection was according to the lowest value of AIC (Akaike information criterion). Parameter estimates from non-linear models were accompanied by $95 \%$ confidence intervals $(95 \% \mathrm{CI})$, which allow making a direct evaluation of how precise estimates were and easily determine statistical differences when intervals do not overlap, contrary to what is possible by providing only standard errors (SE). All analyses were done with the statistical software R version 3.5.1 - 'Feather Spray', The R Foundation for Statistical Computing (R Core Team 2018). Dose-response curves of asymmetrical sigmoid form were fitted with the R package drc (Ritz et al. 2015). Only the case of leaf extract effect on germination of target species was defined by the dose-dependent log-logistic function with four parameters, Eq. (5), which derives from Eq. (4) with a lower asymptote limit $c$. Furthermore, the doses causing 50 or $90 \%$ inhibiting effect on germination $\left(\mathrm{GR}_{[50,90]}\right)$ and radicle elongation $\left(\mathrm{RR}_{[50,90]}\right)$ were calculated.

$$
\begin{aligned}
& f[x(b, d, e)]=\frac{d}{1+\exp \{b[\ln (x)-\ln (e)]\}} \\
& f[x(b, c, d, e)]=c+\frac{d-c}{1+\exp \{b[\ln (x)-\ln (e)]\}}
\end{aligned}
$$

The bioassays to study the allelopathic potential from fractions (see "Fractionation of flower extracts") were analysed by ANOVA to identify the main effects of the factorial experiment, extraction method $\times$ fractions $\times$ target plant species. Successive F tests were applied to reduce model complexity. Tukey ( $\alpha=0.05)$ Honest Significance Difference (HSD) to identify treatment differences, including the general average (AVG), the coefficient of variation (CV) and the HSD value. Further post hoc analysis was applied to the factorial interactions (Ottenbacher 1991), to study whether each fraction interacted differently to each target species according to the extraction method.

\section{Results}

\section{Dose-dependent allelopathic effects}

ANOVA and successive $\mathrm{F}$ test showed strong inhibitory effects of increased concentration $(P<0.0001)$ of both, leaf and flower $C$. haematocephala extracts on the target crops quinoa and rice, as well as, on their corresponding target weeds. More intense effects were generally generated by flower compared with leaf extracts. These effects prevailed for bioassays on quinoa during 2015 and 2016, without any significant difference between years $(P>0.1)$, thus results are presented averaged over years. Lack-of-fit tests and residuals of predicted against fitted values (not shown) determined a good fit of data to the nonlinear models (Figs. 1 and 2).

\section{Quinoa, H. lanatus and C. album}

Seed germination was minimally affected by $C$. haematocephala leaf extract, while radicle elongation was reduced somewhat more (Fig. 1a, c). Apparently, the grass weed HOLLA was visibly more affected than the broad-leaved weed CHEAL or the quinoa crop. However, calculated values for 50 and $90 \%$ germination $\left(\mathrm{GR}_{[50,90]}\right)$ and radicle elongation $\left(\mathrm{RR}_{[50,90]}\right)$ reduction parameters and their corresponding confidence intervals for all target species varied extremely (Table 3 ). Concentration rates of leaf extracts ranged from 0.09 and 6.44 for reflecting the 50 or $90 \%$ inhibiting effect on the target species, correspondingly, and the $95 \%$ CI vary from negative (-31.57) to extremely high positive (44.45) $\mathrm{GR}_{[50,90]}$ and $\mathrm{RR}_{[50,90]}$ values (Table 3 ). Additionally, a slight hormetic effect was observed for the leaf extract on radicle elongation of HOLLA and CHEAL (Fig. 1c). Nevertheless, the log logistic model (4) with three parameters was preferred over a Brain-Cousens model with three parameters plus a hormesis parameter (Belz and Piepho 2012; Ritz et al. 2015), because it allowed calculation of $\mathrm{GR}_{[50,90]}$ and $\mathrm{RR}_{[50,90]}$ values and AIC values were equal for both models.

Flower extract caused a much stronger inhibitory effect than that of leaf extract (Fig. 1b, d and calculated $\mathrm{GR}_{[50,90]}$ and $R_{[50,90]}$ values in Table 3). A selective inhibitory effect towards weed species could be observed, which was more prominent on germination (Fig. 1b) than on radicle elongation (Fig. 1d). Extract concentration rates of 0.18 and 0.30 caused $50 \%$ germination inhibition $\left(\mathrm{GR}_{[50]}\right)$ on HOLLA and CHEAL seeds, while a rate of nearly 0.95 was required to achieve $\mathrm{GR}_{[50]}$ on quinoa seeds (Table 3; Figures A3, A5). No significant inhibition of radicle elongation resulted from flower extract; concentration rates between 0.04 and 0.10 were required to achieve $R_{[50]}$ on all target species (Table 3). A specific inhibitory effect of flower extract towards the target weeds was also seen for $90 \%$ radicle elongation reduction (Figures A4; A6). A concentration rate of 0.22 for both, HOLLA and CHEAL caused $\mathrm{RR}_{[90]}$ (Table 3), while for the same effect on quinoa, a rate of 0.57 was required. However, overlapping 95\% CIs suggest that quinoa was affected as much as the target weed species. 
Fig. 1 Dose-response of increased C. haematocephala extract concentration on target crop quinoa and weeds $C$. album (CHEAL) and H. lanatus (HOLLA). a Leaf extract and b flower extract on germination; $\mathbf{c}$ leaf extract and $\mathbf{d}$ flower extract on radicle elongation. Corresponding estimates for 50 and $90 \%$ germination reduction $\left(\mathrm{GR}_{[50,90]}\right)$ and radicle elongation reduction $\left(\mathrm{RR}_{[50,90]}\right)$ in Table 3

$\rightarrow$ CHEAL $\quad$ - Q Quinoa $\quad \cdots \bullet$ HOLLA

(a)

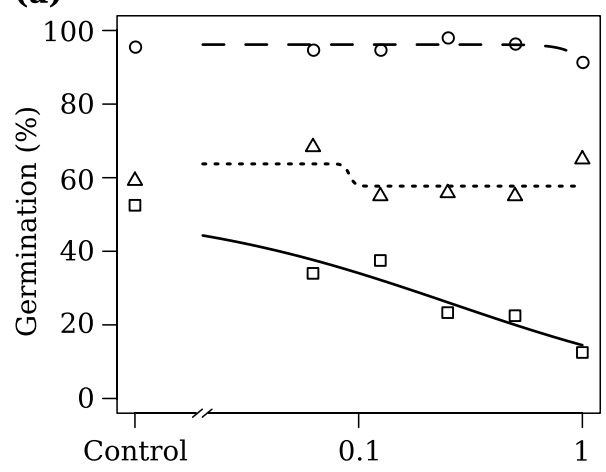

(c)

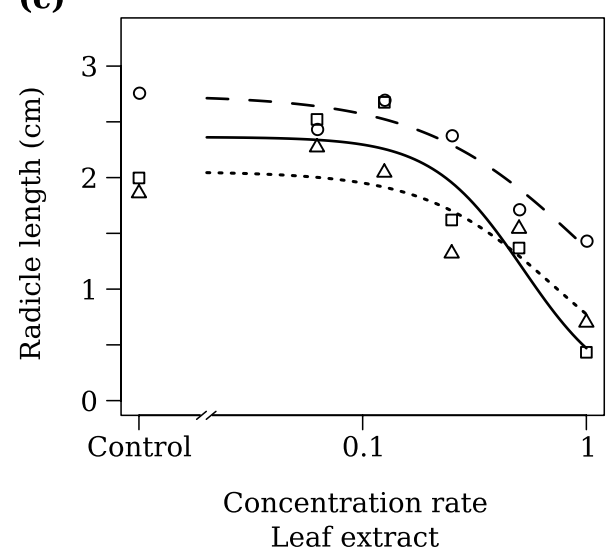

(b)

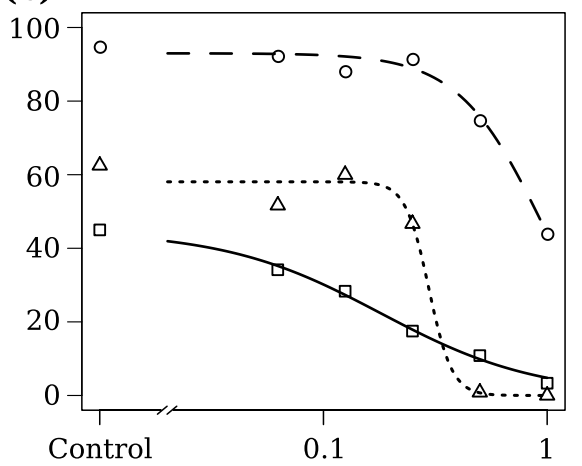

(d)

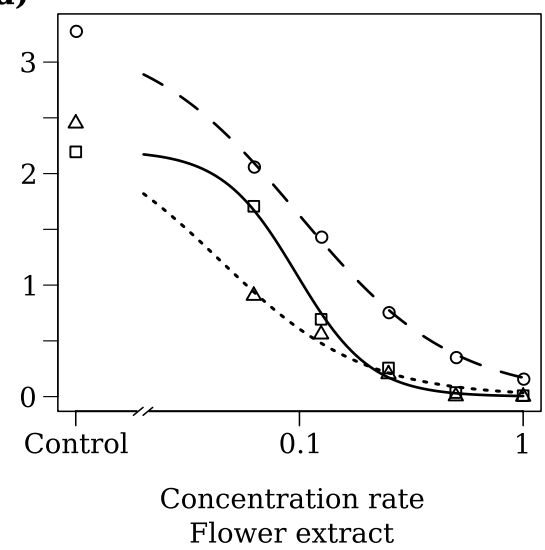

Rice, E. crus-galli, E. colona, E. prostrata and $R$. cochinchinensis

Flower extract of $C$. haematocephala had a weak germination inhibiting effect on seeds of rice and its target weeds, compared with quinoa and target weeds. Overlapping confidence intervals suggested no differences among species (Fig. 2a; Table 3). However, a tendency of selective effects towards weeds prevailed, as rice seed germination was maintained at around $40 \%$, while only $<20 \%$ of the weeds germinated at the $100 \%$-extract concentration. Conversely, radicle elongation was affected by increasing flower extract concentration, being significant for target weeds ECHCG, ECHCO and ECLAL $\left(\mathrm{RR}_{[50]}<0.21\right)$. Seeds of rice and ROOEX were less affected $\left(\mathrm{RR}_{[50]}>0.44\right.$; Fig. 2b; Table 3$)$. Flower extract concentration rates $>0.52$ (CI: $0.14-1.83$ ) was required to reduce $90 \%$ radicle length (Table 3 ), without significant differences for rice and its target weeds. In contrast, overlapping $95 \%$ CIs suggested that radicle elongation inhibition of quinoa was affected by flower extract, as much as its target weed species.

\section{Allelopathy of obtained chemical fractions on target species}

Germination and radicle elongation of the target species were affected differently by the tested fractions, crude extract and tested blanks. The highest germination percentage was obtained with the deionized water blank, averaging nearly $70 \%$ for all target species. The general ANOVA showed significant germination inhibiting effects for all factors and their interactions $(p<0.001)$, except for the factor extraction method $(p=0.08)$. The crude extract (F0) and the fraction containing flavonoids (F3) were ranked as the most inhibiting substances against of all target species (average germination 53.1 and 45.8\%, respectively). This effect was significantly stronger than 


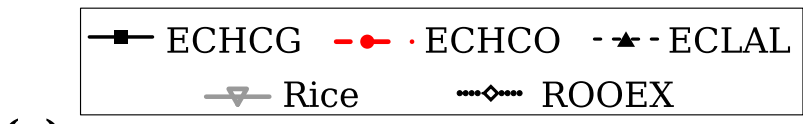

(a)
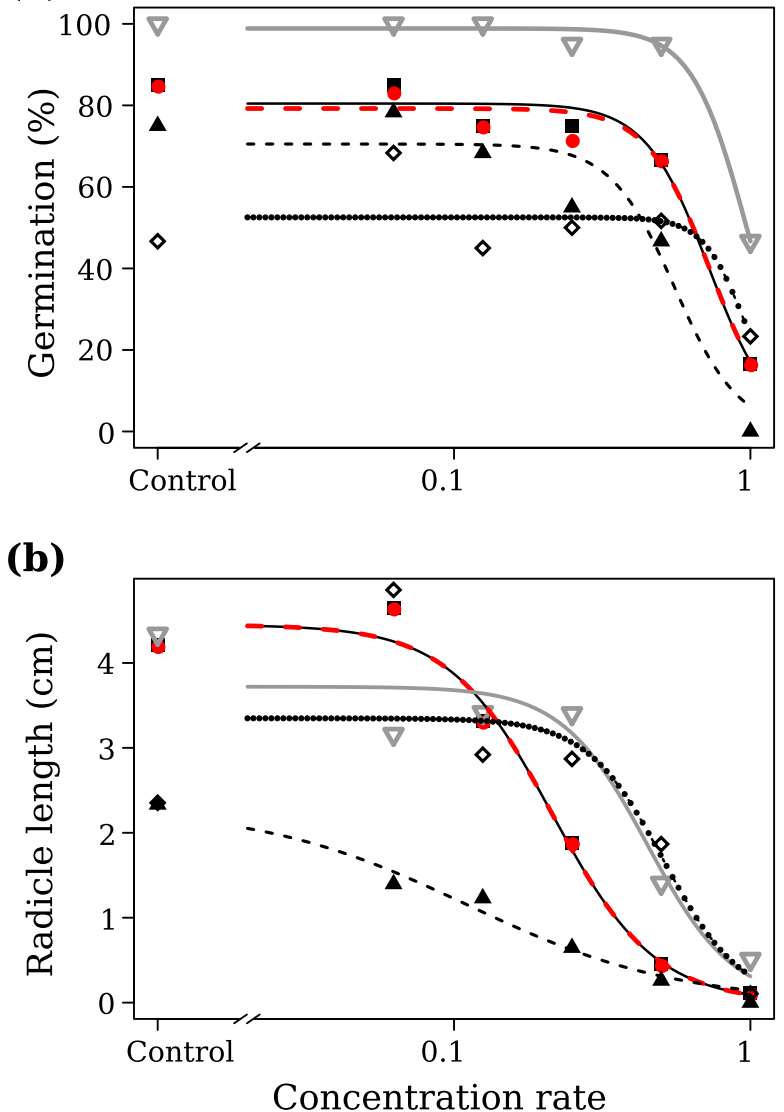

Fig. 2 Dose-response of increased C. haematocephala flower extract concentration on target crop rice and weeds E. crus-galli (ECHCG), E. colona (ECHCO), E. prostrata (ECLAL) and $R$. cochinchinensis (ROOEX). a Germination inhibiting effect; b Root growth reduction effect. Corresponding estimates for 50 and $90 \%$ germination reduction $\left(\mathrm{GR}_{[50,90]}\right)$ and radicle elongation reduction $\left(\mathrm{RR}_{[50,90]}\right)$ in Table 3

the other fractions, according to Tukey HSD comparison (average germination $=59.8 \%, \mathrm{CV}=15.9 \%$ and $\mathrm{HSD}$ =9.6). In addition, some selective effects were detected for the target species $(\mathrm{HSD}=5.0)$. Germination of quinoa (76.4\%) was less affected than its target weeds, and within them, CHEAL was significantly less affected $(\approx 60.1 \%)$ than HOLLA $(\approx 43 \%)$.

The interaction between extraction method and fractions on germination was explained by $\mathrm{F} 0$ and $\mathrm{F} 3$ having a more intense allelopathic effect (Fig. 3; Figures A7, A8). However, the ethanol-based extracts apparently produced a weaker inhibition than the aqueous fractions ground with liquid nitrogen (Fig. 3a). From the aqueous fractions, F0 and $\mathrm{F} 3$ significantly reduced germination by 68.3 and $52.8 \%$, respectively (Tukey $\mathrm{HSD}=15.5$ ). Within the ethanol-based fractions, germination was more affected by the crude extract
F0 (40\%) and fraction F3 (41.2\%), although insignificantly. Moreover, $10 \%$-ethanol blank seemed to affect germination more than the fractions themselves, with a $44 \%$ reduction.

Fractions interacted differently with the target species, significantly reducing the germination of weeds, without affecting quinoa (Fig. 3b; Tukey HSD $=20.2, \mathrm{CV}=15.9 \%$ ). The crude extract (F0) tended to reduce germination of quinoa $(66.7 \%)$ more than F1-F5 (> 70\%), whereas F3 enhanced its germination (80.8\%). F0 and F3 reduced markedly germination of both target weeds, where HOLLA was more affected than CHEAL (Fig. 3b).

The general ANOVA indicated strong effects of extraction method, fractions, target species and interactions between methods against fractions and methods against target species ( $p<0.001)$. Root growth of all target species was reduced by the crude extract F0 and fraction F3 (Fig. 4), from both extraction methods. Ethanol-based extracts showed the strongest inhibitory effect (Fig. 4a). The average radicle length possible under the $10 \%$ ethanol blank and ethanolbased F1, F2, F4 and F5 was nearly $0.8 \mathrm{~cm}$, while under the aqueous blank and corresponding fractions was above $1.2 \mathrm{~cm}(\mathrm{AVG}=0.99 \mathrm{~cm}, \mathrm{CV}=29.96$; $\mathrm{LSD}=0.10)$. Root growth of quinoa was low for the deionized water blank, but radicle length of the target weeds was diminished at a higher level, particularly with fractions F0 and F3 (Fig. 4b). Root length was the lowest for F0 $(0.22 \mathrm{~cm})$ and $\mathrm{F} 3(0.36 \mathrm{~cm})$, compared with the rest of fractions and blanks (1.12-1.40 $\mathrm{cm}$; Tukey HSD $=0.30$ ). Similar to germination, radicle length of target species was selectively reduced by fractions $(\mathrm{HSD}=0.62)$. quinoa and CHEAL were less affected by F3 ( 0.36 and $0.48 \mathrm{~cm}$, respectively) and F0 (0.28 cm both species); HOLLA appeared to be more sensitive to F3 and F0, with 0.23 and $0.09 \mathrm{~cm}$, respectively.

\section{Qualitative and quantitative analysis of fractions}

Using the chemical tests with reagents and TLC, it was possible to detect and quantify allelochemicals in the aqueous and ethanol-based extracts (Table 4; Figure A9). Among the identified phytochemical groups in the aqueous extracts were sesquiterpenes, flavonoids, hydrosoluble tannins, reducing sugars and coumarines (Figure A10). The same phytochemical groups were identified in the ethanol-based extracts, however, with less accuracy and quality. Aqueous extracted F3 produced the most pronounced allelopathic effects. Preparation of F3 allowed determining the flavonoid content in the flower extract through quantification of quercetin, using Eq. (3). Since the fraction density was calculated in $1.03 \mathrm{~g} \mathrm{~mL}^{-1}$, and that $10.65 \mathrm{~g}$ inflorescence were required to produce $50 \mathrm{~mL}$ of $\mathrm{F} 3$, the total quercetin content was determined as $2.67 \mathrm{mg}$ per gram $\mathrm{F} 3$, corresponding to a concentration of $12.82 \mathrm{mg}$ quercetin per gram inflorescence. 
Table 3 Estimates for 50 and $90 \%$ germination reduction $\left(\mathrm{GR}_{[50,90]}\right)$ and radicle elongation reduction $\left(\mathrm{RR}_{[50,90]}\right)$ for the leaf and flower $C$. haematocephala extracts tested on target crops quinoa, rice and target weeds CHEAL, HOLLA, and ECHCG, ECHCO, ECLAL and ROOEX

\begin{tabular}{llllll}
\hline Plant part & Target species & \multicolumn{3}{l}{ Estimates (95\% CI lower/upper) } & \\
\cline { 3 - 6 } & & $\mathrm{GR}_{[50]}$ & $\mathrm{GR}_{[90]}$ & $\mathrm{RR}_{[50]}$ & $\mathrm{RR}_{[90]}$ \\
\hline Leaf & Quinoa & $2.37^{\dagger}(-16.15 / 20.88)$ & $3.34^{\dagger}(-25.91 / 32.58)$ & $1.00(0.36 / 1.63)$ & $6.38(-6.62 / 19.39)$ \\
& CHEAL & $0.26^{\dagger}(-0.48 / 0.99)$ & $6.44^{\dagger}(-31.57 / 44.45)$ & $0.52(0.32 / 0.72)$ & $1.46(0.47 / 2.44)$ \\
& HOLLA & $0.09^{\dagger}(-2.19 / 2.37)$ & $0.10^{\dagger}(-2.11 / 2.30)$ & $0.72(0.29 / 1.14)$ & $3.10(-1.20 / 7.40)$ \\
\multirow{3}{*}{ Flower } & Quinoa & $0.95(0.79 / 1.12)$ & $2.48(1.14 / 3.82)$ & $0.10(0.07 / 0.13)$ & $0.57(0.29 / 0.85)$ \\
& CHEAL & $0.18(0.07 / 0.29)$ & $1.06(0.02 / 2.11)$ & $0.10(0.07 / 0.12)$ & $0.22(0.12 / 0.33)$ \\
& HOLLA & $0.30(0.18 / 0.42)$ & $0.38(0.00 / 0.77)$ & $0.04(0.02 / 0.07)$ & $0.22(0.07 / 0.38)$ \\
& Rice & $0.98(0.85 / 1.10)$ & $1.56(0.62 / 2.51)$ & $0.44(0.31 / 0.59)$ & $0.94(0.14 / 1.73)$ \\
& ECHCG & $0.72(0.57 / 0.88)$ & $1.24(0.79 / 1.70)$ & $0.21(0.14 / 0.28)$ & $0.52(0.25 / 0.80)$ \\
& ECHCO & $0.73(0.58 / 0.89)$ & $1.25(0.78 / 1.71)$ & $0.21(0.14 / 0.28)$ & $0.52(0.24 / 0.80)$ \\
& ECLAL & $0.56(0.37 / 0.74)$ & $0.96(-0.05 / 1.98)$ & $0.11(-0.02 / 0.24)$ & $0.66(-0.50 / 1.83)$ \\
& ROOEX & $0.96(0.73 / 1.20)$ & $1.38(-0.56 / 3.32)$ & $0.51(0.32 / 0.69)$ & $0.98(0.28 / 1.69)$ \\
\hline
\end{tabular}

All parameters were calculated from Eq. (4), except where stated otherwise; 95\% confidence intervals in parentheses †From Eq. (5)



Fig. 3 Effect of the interactions between C. haematocephala extract fractions (F0-F5) and the extraction methods, ethanol $70 \%$ and aqueous-based, including their corresponding blanks on the germination of target species quinoa, C. album (CHEAL) and H. lanatus (HOLLA). a Influence of extraction method; b Effect by target species. The horizontal lines at each observed point is the standard error; significant differences are shown with the symbol $\star$

\section{Discussion}

\section{Allelopathic effects on target species}

Chemical compounds extracted from many plant species have shown allelopathic properties, which give a great hope in the development of non-synthetic alternatives for weed control. Most studies have found allelochemicals mainly in aqueous extracts (Chon et al. 2003; Tsao et al. 2002; Xuan

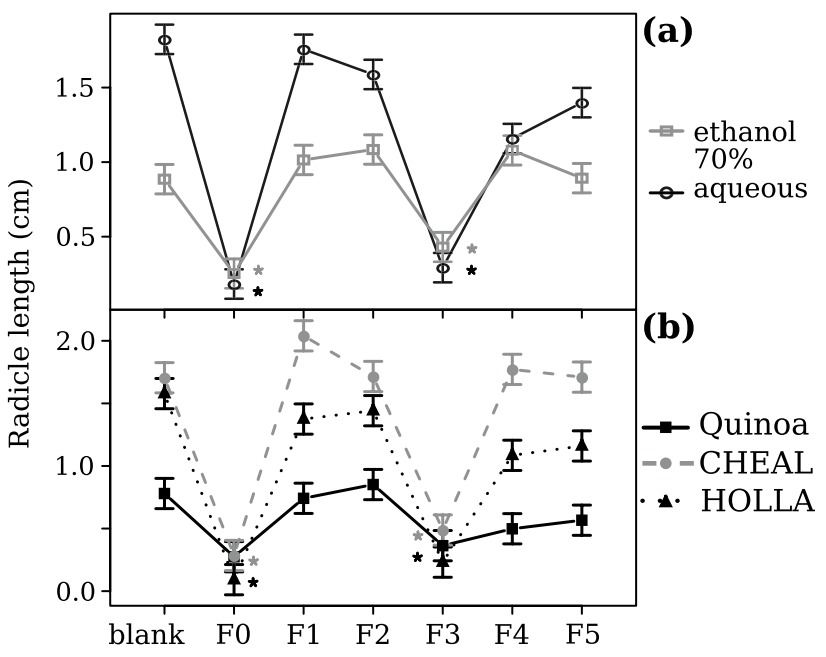

Fig. 4 Effect of the interactions between $C$. haematocephala extract fractions (F0-F5) and the extraction methods, ethanol $70 \%$ and aqueous-based, including their corresponding blanks on radicle elongation of target species quinoa, C. album (CHEAL) and $H$. lanatus (HOLLA). a Influence of extraction method; b Effect by target species. The horizontal lines at each observed point is the standard error; significant differences are shown with the symbol $\star$

et al. 2005; Hill et al. 2007; Reigosa and Pazos-Malvido 2007; Shrestha 2009; Lin et al. 2010; Zhang et al. 2010; Rueda-Ayala et al. 2015; Amari et al. 2014; Puig et al. 2018), describing almost exclusively inhibitory effects towards germination and root elongation. The aqueous extracts of $C$. haematocephala used in this study evidenced a high content of chemical compounds that inhibited the development of target species more than ethanol based extracts. Moreover, a selective effect on weeds without hampering the crop seedlings were observed (Fig. 1). Mixture of extracts from 
Table 4 Results of the phytochemical screening of fractions from $C$. haematocephala flower extracts, obtained after two methods ethanol (10\%) and aqueous (plus grinding with liquid nitrogen)

\begin{tabular}{lllll}
\hline Fraction & Phytochemical group & Extraction method & & Chemical test \\
\cline { 3 - 4 } & & M1: ethanol 70\% & M2: aqueous & \\
\hline F1 & Alkaloids & - & - & \\
F2 & Sterols & - & - & \\
& Sesquiterpenes & + & + & TLC $^{\dagger}$ \\
F3 and (F4) $)^{\ddagger}$ & Terpenes & - & + & Zack's \\
& Flavonoids & $+(-)$ & $+(-)$ & Shinoda's \\
& Anthraquinones & $-(-)$ & $-(-)$ & \\
& Tannins & $+(-)$ & $+(-)$ & Ferric chloride \\
& Saponins & $-(-)$ & $-(-)$ & \\
F5 & Reducing sugars & $+(-)$ & $+(-)$ & Fehling's reagent \\
& Lactones & + & + & Baljet's \\
& Coumarines & - & + & Ferric hydroxamate \\
& Cardiac glycosides & - & - & \\
\hline
\end{tabular}

(Sherma 2000; Seidel 2005; Otsuka 2005; Ivanova-Petropulos et al. 2010; Evans and Evans 2019; Ribeiro et al. 2018). See also Figure A9

${ }^{\dagger}$ Sesquiterpenes were identified after TLC in both extract methods

${ }^{\ddagger}$ All results for F4 were negative different plant structures or plant species have shown higher phytotoxicity than individual extract compounds (Chon et al. 2003). Results in the present study showed much stronger germination and development inhibiting effects by flower than leaf C. haematocephala extracts (Fig. 1).

Some alternative solvents, such as methanol and ethyl acetate produce plant extracts more concentrated with allelochemicals than aqueous extracts (Hill et al. 2007), for instance compounds from methanolic extracts of Everniastrum sorocheilum, Usnea roccellina, and Cladonia confusa have shown growth inhibitory effects on Trifolium pratense (Nieves et al. 2011). Conversely, ethanol-based extracts in this study showed a much lower allelopathic effect on germination (Fig. 3) and radicle elongation (Fig. 4) than aqueous extracts. Aqueous extracts have shown a joint action of several contained compounds at once (Puig et al. 2018).

Apparently, allelochemicals in C. haematocephala are highly concentrated in the above-ground plant structures, although in this study, root extracts were not investigated. Leaf extracts reduced seed germination and radicle elongation of quinoa and its target weeds (Fig. 1a) less efficiently than flower extracts. Flower extracts showed strong inhibiting effects on germination, and even stronger inhibiting effects on radicle elongation (Fig. 1b, d). Hill et al. (2007) found a selective inhibiting effect of allelochemicals on weed species, due to their smaller seed size than that of crops. In this study, quinoa seedlings (C. quinoa) were little affected, while germination and radicle elongation of C. album (CHEAL) was strongly inhibited, even though there was no great difference in seeds size between these two species. Thus, other factors than seed size affected their sensitivity. This selectivity of $C$. haematocephala extracts could offer an advantage in the search of new formulas of bioherbicides for pre-emergence and early emergence use, provided that the involved compounds could be accurately identified. A similar effect occurred with the flower extracts applied to rice and its target weeds, where rice germination was much less affected than that of the target weeds (Fig. 2a). However, the selectivity of flower allelochemicals was somewhat lower for radicle elongation reduction.

\section{Fractions and effects on target species}

Although the same phytochemical groups, except coumarines, were identified in both, aqueous and ethanol-based extracts, the latter yielded lower quantity and quality of allelochemicals. There is evidence that thermolabile and volatile organic compounds, commonly found in plant extracts, are affected by the ethanol maceration (Bart 2011). This effect occurs because the sample remains exposed for longer time to the extracting agent ethanol compared with water. Conversely, grinding the plant sample with liquid nitrogen produces a immediate rupture of the cell wall and cell structures, liberating immediately the metabolites and essential oils, thus reducing losses. Furthermore, the aqueous fractionation to get F3 was extracted from $\frac{1}{3}$ of the crude flower extract (F0), using first petroleum ether and adding a 50:50 methanol/water mixture. These processes allowed separating the residual liquid and to ease the determination of flavonoids, hydrosoluble tannins and reducing sugars in a more efficient 
way. The total flavonoid concentration (regarded as $\mathrm{mg}$ quecetin per $\mathrm{g}$ of inflorescences) was $12.8 \mathrm{mg}$, is comparable with other plant extracts with allelopathic properties. Inhibiting effects of leafs and flowers in Zygophyllum album and Thymelaea hirsuta have been quantified as 4.1 $\mathrm{mg}$ quecetin per $\mathrm{g}$ of the tested plant structure (Amari et al. 2014; Mnafgui et al. 2012, 2016).

\section{Practical implications of $C$. haematocephala flower extracts}

For flower $C$. haematocephala extracts to become a realistic alternative for weed control, the equivalent extract concentration that can be obtained from the harvested fresh inflorescence biomass under field conditions should be determined, more specifically, the field equivalent rate of the F3 fraction. In this study, the fraction F3 was obtained from aqueous and ethanol flower extracts (Table 1, Exps. 6 and 7, respectively). To produce $50 \mathrm{~mL}$ of $\mathrm{F} 3,13.33 \mathrm{~mL}$ of aqueous crude extract were required with a concentration of 2.78 $\mathrm{g} \mathrm{mL}^{-1}$, while $18.33 \mathrm{~mL}$ were required with an ethanol crude extract concentration of $0.56 \mathrm{~g} \mathrm{~mL}^{-1}$. Similarly, $9.26 \mathrm{~mL}$ of F0 were calculated as needed for obtaining F3 in Exps. 3, 4 and 5 (Table 5), at $3.33 \mathrm{~g} \mathrm{~mL}^{-1} \mathrm{~F} 0$ concentration.

Using a similar methodology as proposed by Hill et al. (2007), the field equivalent rates of F3 were calculated (Table 5) with $F E R=(E P) /(A D W)$, where $F E R$ is the field equivalent rate; $E$ is the amount of $\mathrm{F} 3$ fraction $(\mathrm{mL})$ obtainable with the total weight of harvested inflorescence per experiment; $P$ is the petri dish volume used $\left(64 \mathrm{~cm}^{3}\right)$ on the bioassays; $A$ is the area harvested of $C$. haematocephala inflorescence; $D$ is the hypothetical depth at which inflorescence material might be incorporated in the soil $(15 \mathrm{~cm})$, assuming a simultaneous decomposition; and $W$ corresponds to the F3 volume applied to each petri dish. Field equivalent rates of aqueous $\mathrm{F} 3$ fractions ranged between 90 and $143 \mathrm{~mL} \mathrm{l}^{-1}$, while for ethanol, F3 were $131 \mathrm{~mL}^{-1}$. With these estimations, and knowing that $10.65 \mathrm{~g}$ inflorescence yielded $50 \mathrm{~mL} \mathrm{F3}$ (aqueous), the field rates in this study were within the range of concentrations and amount of harvested fresh inflorescence biomass (i.e., 19 to $31 \mathrm{~g} \mathrm{l}^{-1}$ ). However, the extract concentrations achievable from decomposition in the soil will be lower than under laboratory conditions (Hill et al. 2007), results in the present study show a great potential of $C$. haematocephala inflorescence extract for germination and development of weed species, with a high likelihood to be species specific (Figs. 1b, d and 2a; Table 3).

In conclusion, the market supply of bioherbicides is rapidly increasing with to social trends. However, formulation of bioherbicides is still a huge challenge. Less than $10 \%$ of available biopesticides are bioherbicides, while weeds are still the major cause of yield loss in current agriculture (Charudattan 2001). Promising inhibitory effects on seed emergence have been observed from essential oil extracts of eucalyptus (Zhang et al. 2010; Puig et al. 2018) or Black walnut (Shrestha 2009), the latter being already commercially formulated as a bioherbicide that limits completely the growth of Conyza canadensis at a concentration of $33 \%$. The flower extracts identified and tested in this study already fulfill some requirements to be acceptable and efficient biopesticides, such as weed specificity, minimal effect on crops, easy and cheap elaboration. However, other important aspects such as environmental effects, including the production chain, or non-toxicity towards humans and non-target living organisms still require further investigation and validation. Nevertheless, the results of this study are encouraging for finding sustainable and ecologically friendly alternatives for weed management in crops of high nutritional value, as quinoa and rice, contributing also to counteract the growing problem of herbicide resistance.
Table 5 Field equivalent rates (FER) estimated on the approximate $\mathrm{F} 3$ fraction obtainable from $\mathrm{F} 0 C$. haematocephala flower extracts tested in the bioassays

\begin{tabular}{|c|c|c|c|c|c|}
\hline \multirow[t]{2}{*}{ Exp. } & \multirow{2}{*}{$\begin{array}{l}\text { Area harvested } \\
\left(\mathrm{m}^{2}\right)\end{array}$} & \multirow{2}{*}{$\begin{array}{l}\text { Calliandra } \\
\text { height }^{\star}(\mathrm{m})\end{array}$} & \multicolumn{2}{|c|}{ Fractions retrieved } & \multirow{2}{*}{$\begin{array}{l}\text { Field equivalen } \\
\text { rate }\left(\mathrm{mL}^{-1}\right)\end{array}$} \\
\hline & & & $\begin{array}{l}\text { F0 to } 50 \mathrm{~mL} \mathrm{F3} \\
(\mathrm{mL})\end{array}$ & F3 approx..$^{\dagger}(\mathrm{mL})$ & \\
\hline 3 & 1.20 & 2.10 & 9.26 & 761.34 & 90.23 \\
\hline 4 & 0.80 & 2.10 & 9.26 & 734.34 & 130.55 \\
\hline 5 & 1.80 & 2.80 & 9.26 & 1285.10 & 101.54 \\
\hline 6 & 0.25 & 1.70 & 13.33 & 251.31 & 142.97 \\
\hline 7 & 0.25 & 1.70 & 18.33 & 231.86 & 131.90 \\
\hline
\end{tabular}

This amount was calculated on a basis of F0 required to produce $50 \mathrm{~mL}$ of F3. FER were calculated using a similar methodology as Hill et al. (2007). Values in experiments 6 and 7 are true estimates

* Taller shrubs often had more flowers, thus yielding more flower fresh weight per area harvested

${ }^{\dagger}$ Approximate F3 amount calculated from the total crude extract (F0) retrieved at the corresponding experiments in Table 1 
Author contribution statement Conceptualization, design of experiments, methodology for detection of allelopatic properties, statistical analyses, writing-original draft preparation and editing: VPR-A. Methodology for fractionation, qualitative and quantitative analyses of fractions: LR-G, PV-J, DB and LG. Performed bioassays: BH and IT. Draft co-writing and review: LR-G, PV-J, BH, IT, MH and DA. Supervision: VPR-A, LR-G, PV-J and BH.

Acknowledgements Open Access funding provided by Norwegian Institute of Bioeconomy Research. We deeply thank the Ecuadorian Agency for Quality Assurance in Agriculture, AGROCALIDAD, for providing the laboratory facilities, equipment and materials for the bioassays, fractioning and phytochemical screening. Also, thanks to Andrés Rivera for carrying out some of the bioassays and laboratory assessments. No external funding supported this work.

\section{Compliance with ethical standards}

Conflict of interest The authors declare that they have no conflict of interest.

Open Access This article is licensed under a Creative Commons Attribution 4.0 International License, which permits use, sharing, adaptation, distribution and reproduction in any medium or format, as long as you give appropriate credit to the original author(s) and the source, provide a link to the Creative Commons licence, and indicate if changes were made. The images or other third party material in this article are included in the article's Creative Commons licence, unless indicated otherwise in a credit line to the material. If material is not included in the article's Creative Commons licence and your intended use is not permitted by statutory regulation or exceeds the permitted use, you will need to obtain permission directly from the copyright holder. To view a copy of this licence, visit http://creativecommons.org/licenses/by/4.0/.

\section{References}

Amari NO, Bouzouina M, Berkani A, Lotmani B (2014) Phytochemical screening and antioxidant capacity of the aerial parts of Thymelaea hirsuta 1. Asian Pacific J Trop Dis 4(2):104-109. https://doi. org/10.1016/S2222-1808(14)60324-8

Bart HJ (2011) Extraction of Natural Products from Plants - An Introduction, Wiley-VCH Verlag GmbH \& Co. KGaA, pp 1-25. https ://doi.org/10.1002/9783527635122.ch1

Belz RG, Piepho HP (2012) Modeling effective dosages in hormetic dose-response studies. PLoS One 7(3):1-10. https://doi. org/10.1371/journal.pone.0033432

Bhadoria PBS (2011) Allelopathy: a natural way towards weed management. Am J Exp Agric 1:7-20. https://doi.org/10.5281/zenod 0.8091

Charudattan R (2001) Biological control of weeds by means of plant pathogens: significance for integrated weed management in modern agro-ecology. BioControl 46(2):229-260. https://doi. org/10.1023/A:1011477531101

Chon S, Kim Y, Lee J (2003) Herbicidal potential and quantification of causative allelochemicals from several compositae weeds. Weed Res 43(6):444-450. https://doi.org/10.104 6/j.0043-1737.2003.00361.x
Colbach N, Chauvel B, Darmency H, Délye C, Corre VL (2016) Choosing the best cropping systems to target pleiotropic effects when managing single-gene herbicide resistance in grass weeds. a blackgrass simulation study. Pest Manag Sci 72(10):1910-1925. https://doi.org/10.1002/ps.4230

Cordeau S, Triolet M, Wayman S, Steinberg C, Guillemin JP (2016) Bioherbicides: Dead in the water? a review of the existing products for integrated weed management. Crop Prot 87:44-49 j.cropro.2016.04.016

da Silva L, Pezzini B, Soares L (2015) Spectrophotometric determination of the total flavonoid content in Ocimum basilicum 1 . (lamiaceae) leaves. Pharmacogn Mag 11(41):96-101. https://doi. org/10.4103/0973-1296.149721

de Albuquerque MB, dos Santos RC, Lima LM, Melo Filho PdA, Nogueira RJMC, da Câmara CAG, Ramos AdR (2011) Allelopathy, an alternative tool to improve cropping systems. a review. Agron Sustain Dev 31(2):379-395. https://doi.org/10.1051/ agro/2010031

Evans WC, Evans D (2009) Chapter 17 - general methods associated with the phytochemical investigation of herbal products. In: Evans WC, Evans D (eds) Trease and Evans' Pharmacognosy (Sixteenth Edition), sixteenth edition edn, W.B. Saunders, pp 135-147, https ://doi.org/10.1016/B978-0-7020-2933-2.00017-4

Hall KS, Gao S, Unverzagt FW, Hendrie HC (2000) Low education and childhood rural residence. Neurology 54(1):95-95. https:// doi.org/10.1212/WNL.54.1.95

Hill EC, Ngouajio M, Nair MG (2007) Allelopathic potential of hairy vetch (Vicia villosa) and cowpea (Vigna unguiculata) methanol and ethyl acetate extracts on weeds and vegetables. Weed Technol 21(2):437-444. https://doi.org/10.1614/wt-06-167.1

Hossain MA, AL-Raqmi KAS, AL-Mijizy ZH, Weli AM, Al-Riyami Q (2013) Study of total phenol, flavonoids contents and phytochemical screening of various leaves crude extracts of locally grown Thymus vulgaris. Asian Pac J Trop Biomed 3(9):705710. https://doi.org/10.1016/S2221-1691(13)60142-2

Ivanova-Petropulos V, Stefova M, Chinnici F (2010) Determination of the polyphenol contents in macedonian grapes and wines by standardized spectrophotometric methods. J Serb Chem Soc 75:45-59. https://doi.org/10.2298/JSC1001045I

Koocheki A, Lalegani B, Hosseini SA (2013) Ecological Consequences of Allelopathy, Springer Berlin Heidelberg, Berlin, Heidelberg, pp 23-38. https://doi.org/10.1007/978-3-642-30595 $-5 \_2$

Lin L, Song Z, Xu H (2010) A new phenylpropanoid galactoside and other constituents from Pterygota alata (roxb.) r. brown. Biochem Syst Ecol 38(6):1238-1241. https://doi.org/10.1016/j. bse.2010.12.006

Mnafgui K, Hamden K, Ben Salah H, Kchaou M, Nasri M, Slama S, Derbali F, Allouche N, Elfeki A (2012) Inhibitory activities of Zygophyllum album: A natural weight-lowering plant on key enzymes in high-fat diet-fed rats. Evidence-based complementary and alternative medicine. https://doi.org/10.1155/2012/620384

Mnafgui K, Kchaou M, Ben Salah H, Hajji R, Khabbabi G, Elfeki A, Allouche N, Gharsallah N (2016) Essential oil of Zygophyllum album inhibits key-digestive enzymes related to diabetes and hypertension and attenuates symptoms of diarrhea in alloxaninduced diabetic rats. Pharmaceut Biol 54(8):1326-1333. https ://doi.org/10.3109/13880209.2015.1075049

Morrissey CA, Mineau P, Devries JH, Sanchez-Bayo F, Liess M, Cavallaro MC, Liber K (2015) Neonicotinoid contamination of global surface waters and associated risk to aquatic invertebrates: a review. Environ Int 74:291-303. https://doi.org/10.1016/j.envin t.2014.10.024

Nieves J, Acevedo L, Valencia-Islas N, Rojas J, Dávila R (2011) Fitotoxicidad de extractos metanólicos de los líquenes Everniastrum sorocheilum. Usnea roccellina y Cladonia confusa. Glalia 4:96 
Otsuka H (2005) Purification by solvent extraction using partition coefficient. In: Sarker SD, Latif Z, Gray AI (eds) Natural Products Isolation, Humana Press Inc., Totowa, NJ, pp 269-273, https:// doi.org/10.1385/1-59259-955-9:269

Ottenbacher KJ (1991) Interpretation of interaction in factorial analysis of variance design. Stat Med 10(10):1565-1571. https://doi. org/10.1002/sim.4780101008

Puig CG, Reigosa MJ, Valentão P, Andrade PB, Pedrol N (2018) Unravelling the bioherbicide potential of Eucalyptus globulus Labill: Biochemistry and effects of its aqueous extract. PLoS One 13(2):1-16. https://doi.org/10.1371/journal.pone.0192872

R Core Team (2018) R: A Language and Environment for Statistical Computing. R Foundation for Statistical Computing, Vienna, Austria, https://www.R-project.org/

Raja S, Ramesh V, Thivaharan V (2017) Green biosynthesis of silver nanoparticles using Calliandra haematocephala leaf extract, their antibacterial activity and hydrogen peroxide sensing capability. Arab J Chem 10(2):253-261. https://doi.org/10.1016/j.arabj c. 2015.06 .023

Rattner BA (2009) History of wildlife toxicology. Ecotoxicology 18(7):773-783. https://doi.org/10.1007/s10646-009-0354-x

Reigosa MJ, Pazos-Malvido E (2007) Phytotoxic effects of 21 plant secondary metabolites on arabidopsis thaliana germination and root growth. J Chem Ecol 33(7):1456-1466. https://doi. org/10.1007/s10886-007-9318-x

Ribeiro R, de Carvalho M, de Moraes MdL, Rossiello R, de Oliveira D, de Amorim R, Junior EB (2018) Chemical screening of urochloa humidicola: Methods for characterizing secondary metabolites and allelopathic activity on forage legumes. Am J Plant Sci 9(06):1260-1278. https://doi.org/10.4236/ajps.2018.96093

Ritz C, Streibig J (2005) Bioassay analysis using R. J Stat Softw Articles 12(5):1-22. https://doi.org/10.18637/jss.v012.i05

Ritz C, Baty F, Streibig JC, Gerhard D (2015) Dose-response analysis using r. PLoS One 10(12):1-13. https://doi.org/10.1371/journ al.pone. 0146021

Romeo JT (1984) Insecticidal imino acids in leaves of Calliandra. Biochem Syst Ecol 12(3):293-297. https://doi.org/10.1016/03051978(84)90052-8

Rueda-Ayala V, Jaeck O, Gerhards R (2015) Investigation of biochemical and competitive effects of cover crops on crops and weeds. Crop Protect 71:79-87. https://doi.org/10.1016/j.cropr o.2015.01.023

Rueda-Ayala VP, Rasmussen J, Gerhards R (2010) Mechanical weed control. In: Oerke EC, Gerhards R, Menz G, Sikora RA (eds) Precision Crop Protection - the Challenge and Use of Heterogeneity, Springer Netherlands, pp 279-294, https://doi. org/10.1007/978-90-481-9277-9_17,

Schwarzenbach RP, Egli T, Hofstetter TB, von Gunten U, Wehrli B (2010) Global water pollution and human health. Ann Rev Environ Resour 35(1):109-136. https://doi.org/10.1146/annurev-envir on-100809-125342

Seidel V (2005) Initial and bulk extraction. In: Sarker SD, Latif Z, Gray AI (eds) Natural Products Isolation, Humana Press Inc., Totowa, NJ, pp 27-46, https://doi.org/10.1385/1-59259-955-9:27

Sherma J (2000) Thin-layer chromatography in food and agricultural analysis. J Chromatogr A 880(1):129-147. https://doi. org/10.1016/S0021-9673(99)01132-2
Shrestha A (2009) Potential of a black walnut (Juglans nigra) extract product (NatureCur ${ }^{\circledR}$ ) as a pre- and post-emergence bioherbicide. J Sustain Agric 33(8):810-822. https://doi.org/10.1080/10440 040903303397

Souto XC, Gonzales L, Reigosa MJ (1994) Comparative analysis of allelopathic effects produced by four forestry species during decomposition process in their soils in galicia (nw spain). J Chem Ecol 20(11):3005-3015. https://doi.org/10.1007/BF02098405

Streibig JC (1980) Models for curve-fitting herbicide dose response data. Acta Agric Scand 30(1):59-64. https://doi. org/10.1080/00015128009435696

Sulaiman CT, Balachandran I (2012) Total phenolics and total flavonoids in selected indian medicinal plants. Indian J Pharmaceut Sci 74(3):258-260. https://doi.org/10.4103/0250-474X.106069

Thill D, Lish J, Callihan R, Bechinski E (1991) Integrated weed management - a component of integrated pest management: a critical review. Weed Technol 5:648-656. https://doi.org/10.1017/S0890 037X00027500

Tsao R, Deng Z (2004) Separation procedures for naturally occurring antioxidant phytochemicals. J Chromatogr B 812(1):85-99. https ://doi.org/10.1016/j.jchromb.2004.09.028

Tsao R, Romanchuk FE, Peterson CJ, Coats JR (2002) Plant growth regulatory effect and insecticidal activity of the extracts of the tree of heaven (ailanthus altissima 1.). BMC Ecol 2(1):1. https://doi. org/10.1186/1472-6785-2-1

Vonberg D, Vanderborght J, Cremer N, Pütz T, Herbst M, Vereecken $\mathrm{H}$ (2014) 20 years of long-term atrazine monitoring in a shallow aquifer in western germany. Water Res 50:294-306. https://doi. org/10.1016/j.watres.2013.10.032

Webber CL III, Shrefler JW, Brandenberger LP (2012) Organic Weed. Control. https://doi.org/10.5772/32539

Weis M, Keller M, Rueda-Ayala V (2012) Herbicide Reduction Methods, pp 1-28. https://doi.org/10.5772/31908

World Health Organization (2017) Food safety. http://www.who.int/ mediacentre/factsheets/fs399/en/, Accessed on 2018-01-12

Xuan TD, Shinkichi T, Khanh TD, Chung IM (2005) Biological control of weeds and plant pathogens in paddy rice by exploiting plant allelopathy: an overview. Crop Protect 24(3):197-206. https://doi. org/10.1016/j.cropro.2004.08.004

Yadav IC, Devi NL, Syed JH, Cheng Z, Li J, Zhang G, Jones KC (2015) Current status of persistent organic pesticides residues in air, water, and soil, and their possible effect on neighboring countries: a comprehensive review of india. Sci Total Environ 511:123-137. https://doi.org/10.1016/j.scitotenv.2014.12.041

Zhang J, An M, Wu H, Stanton R, Lemerle D (2010) Chemistry and bioactivity of eucalyptus essential oils. Allelopath J 25(2):313-330

Publisher's Note Springer Nature remains neutral with regard to jurisdictional claims in published maps and institutional affiliations. 


\section{Affiliations}

Victor Rueda-Ayala ${ }^{1} \cdot$ Luis Ramos-Guerrero ${ }^{2}$ - Paul Vargas-Jentzsch ${ }^{3} \cdot$ Betty Hernández ${ }^{4} \cdot$ Mats Höglind $^{1}$. Ingrid Toscano ${ }^{5} \cdot$ Dayana Borja $^{5} \cdot$ Lorena Goetschel $^{5} \cdot$ Dionisio Andújar $^{6}$

1 Norwegian Institute of Bioeconomy Research, NIBIO Særheim, Postvegen 213, 4353 Klepp Stasjon, Norway

2 Centro de Investigación de Alimentos, Universidad UTE, Quito, Ecuador

3 Departamento de Ciencias Nucleares, Facultad de Ingeniería Química y Agroindustria, Escuela Politécnica Nacional, Quito, Ecuador
4 Facultad de Ciencias Agrícolas, Universidad Central del Ecuador, Quito, Ecuador

5 Facultad de Ciencias Químicas, Universidad Central del Ecuador, Quito, Ecuador

6 Centre for Automation and Robotics, CSIC-UPM, Arganda del Rey 28500 Madrid, Spain 